\title{
Fatal asphyxia due to laryngeal displacement by large-sized prey in a Guiana dolphin
} (Sotalia guianensis), Brazil

\section{Daniela Bueno Mariani, ${ }^{1,2}$ Juliana Plácido Guimarães ${ }^{1,3}$ Renata Guedes Batista $^{1}$ Andrei Brum ${ }^{1}$ Kátia Regina Groch ${ }^{4}$ (D) Josué Díaz-Delgado ${ }^{5^{*}}$ (D) Jociery Einhardt Vergara Parente ${ }^{1,6}$}

\author{
${ }^{1}$ Fundação Mamíferos Aquáticos, Núcleo dos Efeitos Antropogênicos nos Recursos Marinhos, Hospital Veterinário da Faculdade Pio Décimo. \\ Aracaju, SE, Brasil. \\ ${ }^{2}$ Programa de Pós-graduação em Medicina Veterinária, Universidade Federal Rural de Pernambuco (UFRPE), Recife, PE, Brasil \\ ${ }^{3}$ Programa de Pós-Graduação em Sustentabilidade de Ecossistemas Costeiros e Marinhos, Universidade Santa Cecília/Santos, SP, Brasil. \\ ${ }^{4}$ Laboratório de Patologia Comparada de Animais Silvestres, Departamento de Patologia, Faculdade de Medicina Veterinária e Ciência Animal, \\ Universidade de São Paulo (USP), 05508-270, São Paulo, SP, Brasil. E-mail: josue.diazdelgado@tvmdl.tamu.edu. "Corresponding author. \\ ${ }^{5}$ Texas A\&M Veterinary Medical Diagnostic Laboratory, 483 Agronomy Rd, College Station, 77843, TX, US. \\ ${ }^{6}$ Instituto de Tecnologia e Pesquisa, Farolândia, Aracaju, SE, Brasil.
}

ABSTRACT: The Guiana dolphin (Sotalia guianensis) is a small odontocete distributed from Santa Catarina state, Brazil, to Honduras. Although it is currently considered "near threatened" by the International Union for Conservation of Nature, considerable knowledge on health and disease aspects of this species has been gained over the last decade. The main threats for the species are represented by multiple anthropic factors. Guiana dolphins feed on a variety of taxa, primarily teleosts, crustaceans, and cephalopods. Herein, we reported a case of severe laryngeal displacement and esophageal impaction with ulceration associated with a deglutted adult leatherjacket (Oligoplites sp.). This fish species is not a common prey item of Guiana dolphins'diet. Severe upper aerodigestive compromise likely led to death by mechanical asphyxia (choke) in this dolphin. This report attested the occurrence of upper aerodigestive dysfunction due to overzealous feeding in Guiana dolphin and contributed to general knowledge on pathology of the species.

Key words: deglutition, larynx, cetacean, pathology, predator-prey interaction, impaction, esophageal ulcer.

Asfixia por deslocamento laríngeo associado a consumo de presa de grande tamanho em boto-cinza (Sotalia guianensis), Brasil

RESUMO: O boto-cinza (Sotalia guianensis) é um pequeno odontoceto que ocorre desde o estado de Santa Catarina, Brasil, até Honduras. Embora esta espécie seja considerada “quase ameaçada” pela União Internacional para a Conservação da Natureza, um considerável conhecimento sobre diversos aspectos de saúde e doença nesta espécie foi adquirido na última década. As principais ameaças para a espécie são representadas por múltiplos fatores antrópicos. Os botos-cinza se alimentam de uma variedade de táxons, incluindo principalmente teleósteos, crustáceos e cefalópodes. No presente estudo relatamos um caso de deslocamento laríngeo grave e impactação esofágica com ulceração pela deglutição de um peixe adulto do gênero Oligoplites. Esta espécie de peixe não é um elemento comum da dieta dos botos-cinza. É possivel que o comprometimento aerodigestivo grave tenha levado o animal à morte por asfixia mecânica. Este relato atesta a ocorrência de disfunção aerodigestiva superior devido à alimentação de tamanho excessivo por um boto-cinza, e contribui para o conhecimento geral de patologias na espécie.

Palavras-chave: deglutição, laringe, cetáceos, patologia, interação predador-presa, impactação, úlcera esofágica.

The Guiana dolphin (Sotalia guianensis) is widely distributed along the western Atlantic, from Santa Catarina state, Brazil (SIMÕES-LOPES, 1988; BOROBIA et al., 1991) to Honduras (SILVA \& BEST, 1996). This species tends to occur in neritic coastal waters such as estuaries and bays (SILVA \& BEST, 1994) and has shown residency patterns (site fidelity) in various areas along the Brazilian Atlantic coast (ROSSI-SANTOS et al., 2007; HARDT et al., 2010; CANTOR et al., 2012; BATISTA et al., 2014; OSHIMA \& SANTOS, 2016; DE MELLO et al.,
2019). The main threats to the species are represented by multiple anthropic factors, predominately fatal interactions with fishing gear (SILVA \& BEST, 1994).

The feeding behavior of this species does not seem to diverge from other odontocetes of the Delphinidae family (PANSARD et al., 2011). Prey selection is influenced by several factors such as prey palatability, availability, flee response, and size. Furthermore, the size of the buccal apparatus of the predator and deglutition process condition and modulate feeding habits. Guiana dolphins feed 
on a variety of taxa, primarily teleosts, crustaceans, and cephalopods (ZANELATO, 2001; SANTOS et al., 2002; GURJÃO et al., 2003; DI BENEDITTO \& SICILIANO, 2007; DAURA-JORGE et al., 2011; CREMER et al., 2012).

In general, the respiratory system of cetaceans follows a similar pattern to terrestrial mammals; however, cetaceans developed multiple adaptive changes in the upper and lower respiratory tract. Specifically, they developed anatomorphological changes in the upper airways to avoid aspiration while feeding. The larynx (so-called "goosebeak") is composed of an elongated epiglottis and corniculate cartilage (REIDENBERG \& LAITMAN, 1987). The goosebeak extends through a small opening in the esophagus into the nasal passage and is further sealed by the palatopharyngeal sphincter muscle so food can pass to either side of the goose beak (PABST et al., 1999). There is still some debate on whether the odontocete larynx is retractile or fixed in the distal nasal passage (REIDENBERG \& LAITMAN, 1987). Despite this anatomical adaptation, few reports have documented fatal laryngeal displacement associated with large fish lodged in the cranial esophagus and foreign bodies (BYARD et al., 2003; WATSON \& GEE, 2005; MIGNUCCI-GIANNONI et al., 2009). In these cases, the displaced larynx opens to the upper digestive system and is vulnerable to compression and/or obstruction, which may lead to death by asphyxia or suffocation (STOLEN et al., 2013). This study aimed to describe the pathologic findings in a case of severe laryngeal displacement and esophageal impaction and ulceration by a deglutted adult leatherjacket (Oligoplites sp.) that led to asphyxia and death in a Guiana dolphin.

A 1.86 m-long, adult, female Guiana dolphin in good body condition and moderate autolysis was found stranded dead in 'praia de Ponta dos Mangues,' Pacatuba municipality, northern Sergipe (Brazil; $10^{\circ} 36^{\prime} \mathrm{S} ; 36^{\circ} 38^{\prime} \mathrm{W}$ ) on November 25,2011 . The carcass was retrieved during routine monitoring under the 'Programa Regional de Monitoramento de Encalhes e Anormalidades PRMEA' carried out by 'Fundação Mamíferos Aquáticos - FMA' and immediately submitted for necropsy to the pathology laboratory at Pio Décimo University in Aracaju, Sergipe. Representative tissue samples from heart, lung, trachea, mediastinal and tracheobronchial lymph nodes, diaphragm, tongue, stomach, intestine, liver, kidney, urinary bladder, spleen, pancreas, ovary, uterus, skin, and skeletal muscle were collected and fixed in $10 \%$ neutral buffered formalin. All these tissues were processed routinely, embedded in paraffin-wax and $5 \mu \mathrm{m}$-thick sections were stained with hematoxylin and eosin (H\&E) for microscopic analysis. Identification of partially deglutted fish relied on morphologic features (ARAÚJO et al., 2004).

On necropsy examination, the main gross findings involved the upper respiratory and digestive systems. Protruding through the mouth there was a caudal fin of a fish (Figure 1A). Upon dissection of the esophagus, a $64 \mathrm{~cm}$-long adult leatherjacket (Oligoplites sp.) occupied and distended the oropharynx and the cervical and thoracic esophagus to the esophageal hiatus (impaction). The fish markedly displaced left-laterally and cranio-ventrally the epiglottis and corniculate cartilages, precluding communication with the nasal passage (Figure 1B). Focally, multiple hard rays of the anterior and posterior dorsal fin penetrated the overlying esophageal mucosa, which was linearly ulcerated over $7.3 \mathrm{~cm}$ on its dorsal aspect (Figure 1C). There was local hyperemia, edema, and hemorrhage. An additional relevant gross finding was moderate pulmonary Halocercus brasiliensis infestation.

Microscopically, the affected esophageal mucosa presented deep, locally extensive ulceration down to the longitudinal muscle layer and acute inflammation composed of edema, hemorrhage, necrosis and mild infiltration of neutrophils and fibrin. In the lungs, there was moderate, multifocal, chronic bronchointerstitial pneumonia with scattered pyogranulomas, adult $H$. brasiliensis nematodes, bacteria, edema, alveolar histiocytosis and interstitial and pleural fibrosis. Often, the intrapulmonary arteries had tunica media hypertrophy/hyperplasia and angiomatosis. There were no other relevant histopathologic findings. Based on the above findings, a diagnosis of severe laryngeal displacement secondary to esophageal distension and impaction by a large-sized deglutted adult Oligoplites sp. was determined.

Occasionally, ingested food items or prey diverge from those considered within the regular diet pattern for an individual. In these cases, consumption could be related to temporary lack of availability of common prey species or punctual feeding behavior alterations of the predator (SILVA, 1999). In the present case, the fish ingested belonged to the genus Oligoplites (family Carangidae), which is distributed throughout coastal and oceanic pelagic habitats of tropical and subtropical latitudes, from Honduras to Uruguay. Guiana dolphins are known to prey on a wide variety of teleosts. However, diet studies on this species suggested neither Oligoplites sp. nor 


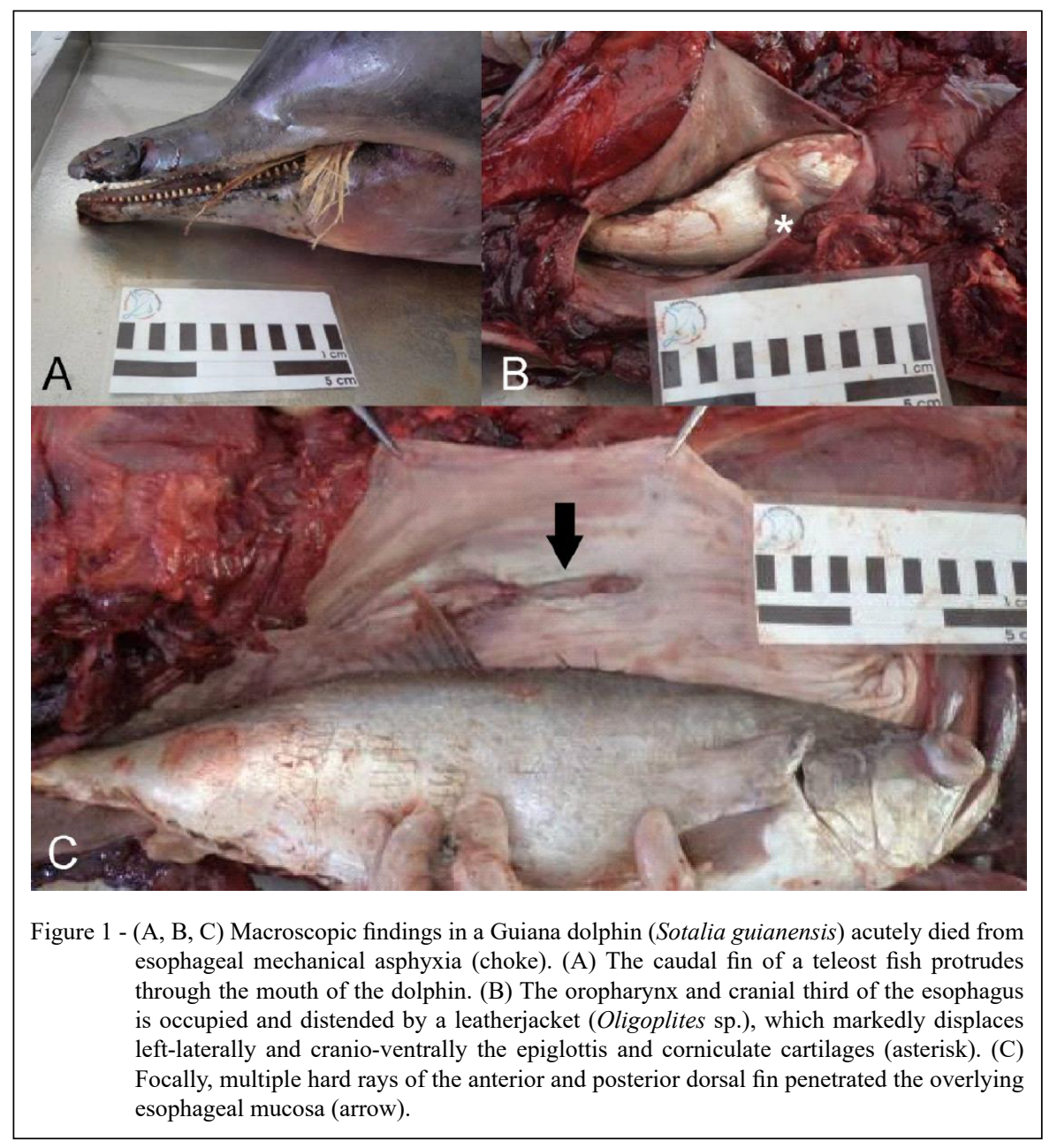

carangids in general, are primary prey items in the species (SANTOS et al., 2002; GURJÃO et al., 2003; DI BENEDITTO \& SICILIANO, 2007; DAURAJORGE et al., 2011; CREMER et al., 2012). Yet, various carangids have been recorded in Guiana dolphins off Brazil (PANSARD et al., 2011; LOPES et al., 2012; RUPIL et al., 2018).

A large number of teleosts has been identified in gastric contents of Guiana dolphins (SANTOS et al., 2002; GURJÃO et al., 2003; DI BENEDITTO \& SICILIANO, 2007; DAURAJORGE et al., 2011; PANSARD et al., 2011; CREMER et al., 2012; LOPES et al., 2012; RUPIL et al., 2018). Furthermore; although, studies on Guiana dolphin's diet reported size-range variation for prey items, from 4.32 to $77 \mathrm{~cm}$-long (PANSARD et al., 2011), the average total length of preys ingested is between $13.18 \mathrm{~cm}$-long (PANSARD et al., 2011) to $20 \mathrm{~cm}$-long (DAURA-JORGE et al., 2011). Even though some preyed fish, primarily swordfish (Trichiurus lepturus) were $77 \mathrm{~cm}$-long, no laryngeal displacement was recorded in any of the dolphins studied (DAURA-JORGE et al., 2011). Noteworthy, the swordfish has an elongated (fusiform) shape and; therefore, despite its total length, it does not have large circumference and biomass, thus, it might not interfere with deglutition. As Guiana dolphins tend to choose their prey based on their size, capture difficulty, their buccal limitations, and digestive tract features and because of the relatively rarity of this species as a prey item in Guiana dolphins, it was hypothesized that the present case constitutes a fatal sporadic event.

There are several published reports of laryngeal displacement occurrence in odontocetes. Severe laryngeal strangulation has been documented 
in bottlenose dolphins (Tursiops truncatus), associated with fishing gears leading to digestive dysfunction and starvation (GOMERČIĆ et al., 2009; LEVY et al., 2009). Larynx strangulation was reported only in adult animals and appeared more often in animals with reduced ability to catch free-swimming prey, as suggested by dental wear and/or tooth rupture noted in most of them (GOMERČIĆ et al., 2009). Asphyxia was not directly associated with laryngeal strangulation in these cases. Grossly, the animals presented ulcerating and strangulating disruption of the mucosa with edema and reparative attempts characterized by granulation tissue proliferation. Microscopically, chronically traumatized laryngeal tissue had necrosis, pleocellular inflammatory infiltrates, and secondary bacterial overgrowth. These lesions led to increased vulnerability to foreign body aspiration and precluded feeding, leading towards chronic debilitating condition characterized by cachexia and low resistance. Other studies have documented fatal asphyxia due to overzealous feeding, involving ingestion of large-sized teleost or cephalopod preys (SIEBERT et al., 2001 ; BYARD et al., 2003; WATSON \& GEE, 2005; BYARD et al., 2010; IJSSELDIJK et al., 2015; STEPHENS et al., 2017). In the Indian River Lagoon, Florida, 14 of 350 stranded and evaluated bottlenose dolphins presented with asphyxia due to laryngeal displacement by ingested fish that greatly distended the esophagus. In five of these cases, the fish protruded partially through the mouth. The fish species linked to laryngeal displacement in these cases were: the sheepshead (Archosargus probatocephalus), the black chin tilapia (Sarotherodon melanotheron), the striped mojarra (Eugerres plumieri), and several cichlids (family Carangidae). These fish had a total length ranging from 19 to $40 \mathrm{~cm}$ (STOLEN et al., 2013). The authors concluded that choking in these cases was more likely related to selection of deep-bodied prey fish species with strong dorsal spines and occasional secondary association with fishing gear. Preyed fish total length was regarded a minor factor in these cases. Prey abundance and dolphin behavior were regarded as the main factors involved in such prey selections (STOLEN et al., 2013).

Recently, cases of laryngeal luxation involved the Maori octopus (Macroctopus maorum) in Indo-Pacific bottlenose dolphin, leading to laryngeal luxation and asphyxiation (STEPHENS et al., 2017); common soles (Solea solea) stuck in the nasal cavity of long-finned pilot whales, and common soles in the nasal cavity of harbor porpoises (Phocoena phocoena) (IJSSELDIJK et al., 2015).
In summary, we documented the first case of severe laryngeal displacement and esophageal impaction with ulceration by a large-sized deglutted adult leatherjacket (Oligoplites sp.) in a Guiana dolphin. The severity of this process coupled with no further evidence of lethal concomitant disease processes, suggested the animal suffered acute mechanical asphyxia (choke) leading to death. Besides contributing to feeding ecology knowledge for this species, our findings demonstrate this species may also suffer from laryngeal displacement due to sporadic large prey items. This pathologic process should be contemplated as a differential diagnosis for acute death in Guiana dolphins.

\section{ACKNOWLEDGEMENTS}

The authors would like to thank 'Faculdade Pio Décimo', 'Projeto Tamar', and Heyder Luiz Cavalcante de Campos e Victor Roncaglione for logistical support. This study employed data generated by the SubRegional Program for Stranding and Abnormal Activity Monitoring, as a mitigating measure of the Federal Environmental Licensing conducted by the Brazilian environmental Agency IBAMA. We very much appreciate the support of Coordination for the Improvement of Higher Education Personnel (CAPES) and São Paulo Research Foundation (FAPESP) for the fellowships \#2014/24932-2 (KRG) and \#2017/02223-8 (JDD).

\section{BIOETHICS AND COMMITTEE APPROVAL}

BIOSSECURITY

We authors of the article entitled "Fatal asphyxia due to laryngeal displacement by large-sized prey in a Guiana dolphin (Sotalia guianensis), Brazil" declared, for all due purposes, the project that gave rise to the present data of the same has not been submitted for evaluation to the Ethics Committee of the University /Research Institute "Fundação Mamíferos Aquáticos/Núcleo dos Efeitos Antropogênicos nos Recursos Marinhos", but we are aware of the content of the Brazilian resolutions of the National Council for Control of Animal Experimentation - CONCEA "http://www. mct.gov.br/index.php/content/view/310553.html" if it involves animals." Thus, the authors assume full responsibility for the presented data and are available for possible questions, should they be required by the competent authorities.

\section{DECLARATION OF CONFLICT OF INTERESTS}

The authors declare no conflict of interest. The founding sponsors had no role in the design of the study; in the collection, analyses, or interpretation of data; in the writing of the manuscript, and in the decision to publish the results.

\section{AUTHORS' CONTRIBUTIONS}

DBM, JPG, RGB, AB and JEVP performed gross postmortem examination. JD-D and $\mathrm{KG}$ performed 
histopathological examinations and prepared the final version of the manuscript. All authors contributed to the draft of the manuscript, critically revised the manuscript and approved the final version.

\section{REFERENCES}

ARAÚJO, M.E., et al. Peixes estuarinos marinhos do nordeste brasileiro. Fortaleza: Universidade Federal do Ceará, 2004. 260p.

BATISTA, R. L. G., et al. Site fidelity and habitat use of the Guiana dolphin, Sotalia guianensis (Cetacea: Delphinidae), in the estuary of the Paraguaçú River, northeastern Brazil. North-Western Journal of Zoology, v.10, n.1. 2014. Available from: <http:// biozoojournals.ro/nwjz/content/v10n1/nwjz_131802_Batista. pdf>. Accessed: Sep. 28, 2019. doi: 131802.

BOROBIA, M., et al. Distribution of the South American dolphin Sotalia fluviatilis. Canadian Journal of zoology, v.69, n.4, p.10251039. 1991. Available from: <https://www.nrcresearchpress.com/ doi/abs/10.1139/z91-148\#.XY9sey5KjIU>. Accessed: Sep. 28, 2019. doi: doi.org/10.1139/z91-148.

BYARD, R. W., et al. Cetacean café coronary. Journal of clinical forensic medicine, v.10, n.2, p.85-8. 2003. Available from: $\quad<$ https:/www.sciencedirect.com/science/article/pii/ S1353113103000099?via\%3Dihub>. Accessed: Sep. 28, 2019. doi: 10.1016/S1353-1131(03)00009-9.

BYARD, R. W., et al. Unusual causes of fatal upper aerodigestive tract obstruction in wild bottlenose dolphins (Tursiops aduncus). Forensic science, medicine, and pathology, v.6, n.3, p.20710. 2010. Available from: <https:/www.ncbi.nlm.nih.gov/ pubmed/20165933>. Accessed: Sep. 28, 2019. doi: 10.1007/ s12024-010-9143-3.

CANTOR, M., et al. Assessing population parameters and trends of Guiana dolphins (Sotalia guianensis): An eight-year markrecapture study. Marine Mammal Science., v.28, n.1, p.63-83. 2012. Available from: $<$ http://www.lamaq.ufsc.br/files/2013/10/76Cantor-20121.pdf>. Accessed: Sep. 28, 2019. doi: 10.1111/j.17487692.2010.00456.x.

CREMER, M. J., et al. Prey consumed by Guiana dolphin Sotalia guianensis (Cetacea, Delphinidae) and franciscana dolphin Pontoporia blainvillei (Cetacea, Pontoporiidae) in an estuarine environment in southern Brazil. Iheringia, Série Zoologia, Porto Alegre, v.102, n.2, p.131-137. 2012. Available from: $\quad<$ http://www.scielo.br/scielo.php?script=sci_arttext\&pid $=$ S0073-47212012000200003 $>$. Accessed: Sep. 28, 2019. doi: $10.1590 / \mathrm{S} 0073-47212012000200003$

DAURA-JORGE, F. G., et al. Feeding habits of the Guiana dolphin, Sotalia guianensis (Cetacea: Delphinidae), in Norte Bay, southern Brazil. Scientia Marina, v.75, n.1, p.163-169. 2011. Available from: $<$ http://lamaq.paginas.ufsc.br/files/2013/10/Daura-Jorge et al_2011__Feeding_habits_of_Sotalia_guianensis_in_Norte_Bay. pdf $>$. Accessed: Sep. 28, 2019. doi: 10.3989/scimar.2011.75n1163.

DE MELLO, A. B., et al. Abundance estimates of Guiana Dolphins (Sotalia guianensis; Van Bénéden, 1864) Inhabiting an Estuarine System in Southeastern Brazil. Aquatic Mammals, v.1, n.45. 2019. Available from: <https://bdpi.usp.br/item/002942190> Accessed: Sep. 28, 2019. doi: 10.1578/AM.45.1.2019.56.

DI BENEDITTO, A. P. M.; S. SICILIANO. Stomach contents of the marine tucuxi dolphin (Sotalia guianensis) from Rio de
Janeiro, southeastern Brazil. Journal of the Marine Biological Association UK, v.87, p.253-254. 2007. Available from: <https:// www.cambridge.org/core/journals/journal-of-the-marinebiological-association-of-the-united-kingdom/article/stomachcontents-of-the-marine-tucuxi-dolphin-sotalia-guianensis-fromrio-de-janeiro-southeastern-brazil/0466D3521C2B1312F58D 2BDFE78B9DBB $>$. Accessed: Sep. 28, 2019. doi: 10.1017/ S0025315407053647.

GOMERČIĆ, M., et al. Bottlenose dolphin (Tursiops truncatus) depredation resulting in larynx strangulation with gillnet parts. Marine Mammal Science, v.25, n.2, p.392-401. 2009. Available from: <https://onlinelibrary.wiley.com/doi/full/10.11 11/j.1748-7692.2008.00259.x>. Accessed: Sep. 28, 2019. doi: 10.1111/j.1748-7692.2008.00259.x.

GURJÃO, L. M., et al. Feeding habits of marine tucuxi, Sotalia fluviatilis, at Ceará State, northeastern Brazil. Latin American Journal of Aquatic Mammals, v.2, n.2, p.117-122. 2003. Available from: <http:/www.lajamjournal.org/lajam/index.php/ lajam/article/viewFile/184/136>. Accessed: Sep. 28, 2019. doi: 10.5597/lajam00040.

HARDT, F. A., et al. Residence patterns of the Guiana dolphin Sotalia guianensis in Babitonga Bay, south coast of Brazil. Latin American Journal of Aquatic Mammals, v.8, n.1-2, p.117-121. 2010. Available from: <http://lajamjournal.org/index.php/lajam/article/view/337>. Accessed: Sep. 28, 2019. doi: doi.org/10.5597/lajam00160.

IJSSELDIJK, L. L., et al. Fatal asphyxiation in two long-finned pilot whales (Globicephala melas) caused by common soles (Solea solea). PloS one, v.10, n.11, p.p.e0141951. 2015. Available from: <https:// journals.plos.org/plosone/article?id=10.1371/journal.pone.0141951>. Accessed: Sep. 28, 2019. doi: 10.1371/journal.pone.0141951.

LEVY, A. M., et al. Laryngeal snaring by ingested fishing net in a common bottlenose dolphin (Tursiops truncatus) off the Israeli shoreline. Journal of wildlife diseases, v.45, n.3, p.834838. 2009. Available from: <https://www.jwildlifedis.org/doi/ abs/10.7589/0090-3558-45.3.834>. Accessed: Sep. 28, 2019. doi: $10.7589 / 0090-3558-45.3 .834$

LOPES, X. M., et al. Feeding habits of Guiana dolphins, Sotalia guianensis, from south-eastern Brazil: new items and a knowledge review. Journal of the Marine Biological Association of the United Kingdom, v.92, n.8, p.1723-33. 2012. Available from: <https://www.cambridge.org/core/journals/journal-ofthe-marine-biological-association-of-the-united-kingdom/ article/feeding-habits-of-guiana-dolphins-sotalia-guianensisfrom-southeastern-brazil-new-items-and-a-knowledge-review/ DF949BE190AEFBBD8A60F555890C832F > . Accessed: Sep. 28, 2019. doi: 10.1017/S0025315412000495.

MIGNUCCI-GIANNONI, A. A., et al. Asphyxiation in a bottlenose dolphin (Tursiops truncatus) from Puerto Rico due to choking on a black margate (Anisotremus surinamensis). Aquatic Mammals, v.35, n.1, p.48. 2009. Available from: <https://search.proquest. com/docview/197729233?pq-origsite $=$ gscholar $>$. Accessed: Sep. 28, 2019. doi: 10.1578/AM.35.1.2009.48.

OSHIMA, J. E.; M. C. SANTOS. Guiana dolphin home range analysis based on 11 years of photo-identification research in a tropical estuary. Journal of Mammalogy, v.4, n.97, p.599-610. 2016. Available from: <https://academic.oup.com/jmammal/ article/97/2/599/2459764> . Accessed: Sep. 28, 2019. doi: 10.1093/ jmammal/gyv207. 
PABST, D. A., et al. The functional morphology of marine mammals. In: J. E. Reynolds e S. A. Rommel (Ed.). Biology of Marine Mammals. Washington, D.C.: Smithsonian Institution Press, The functional morphology of marine mammals, p.15-72; 1999.

PANSARD, K. C. A., et al. Feeding ecology of the estuarine dolphin (Sotalia guianensis) on the coast of Rio Grande do Norte, Brazil. Marine Mammal Science, v.27, n.4, p.673-687. 2011. Available from: <https://onlinelibrary.wiley.com/doi/full/10.11 11/j.1748-7692.2010.00436.x>. Accessed: Sep. 28, 2019. doi: 10.1111/j.1748-7692.2010.00436.x.

REIDENBERG, J. S.; J. T. LAITMAN. Position of the larynx in Odontoceti (toothed whales). Anat Rec, v.218, p.98-106. 1987. Available from: <https://onlinelibrary.wiley.com/doi/abs/10.1002/ ar.1092180115>. Accessed: Sep. 28, 2019. doi: 10.1002/ar.1092180115.

ROSSI-SANTOS, M. R., et al. Residence and site fidelity of Sotalia guianensis in the Caravelas River Estuary, eastern Brazil. Journal of the Marine Biological Association of the United Kingdom, v.87, n.1, p.207-212. 2007. Available from: <https://www. cambridge.org/core/journals/journal-of-the-marine-biologicalassociation-of-the-united-kingdom/article/residence-and-sitefidelity-of-sotalia-guianensis-in-the-caravelas-river-estuaryeastern-brazil/A3A50DB54D0FCE5D3716D08A0A0B97EC $>$. Accessed: Sep. 28, 2019. doi: 10.1017/S0025315407055683.

RUPIL, G. M., et al. Climate influences on Guiana dolphin diet along the Brazilian coast. Scientia Marina, v.82, n.3, p.159-68. 2018. Available from: $<$ http://scientiamarina.revistas.csic.es/index. php/scientiamarina/article/view/1766>. Accessed: Sep. 28, 2019. doi: $10.3989 /$ scimar.04775.27A.

SANTOS, M. C. O., et al. Insights on small cetacean feeding habits in southeastern Brazil. Aquatic Mammals, v.28, p.3845. 2002. Available from: <https://www.researchgate.net/profile/ Roberta_Aguiar_Dos_Santos/publication/233782316_Insights on_small_cetacean_feeding_habits_in_southeastern_Brazi1/ links/0fcfd50b7524cb2ff8000000.pdf>. Accessed: Sep. 28, 2019. doi: 10 -e20190213.

SIEBERT, U., et al. Post-mortem findings in harbour porpoises (Phocoena phocoena) from the German North and Baltic Seas. Journal of comparative pathology, v.124, n.2-3, p.102-14. 2001. Available from: <https://www.sciencedirect.com/science/article/ pii/S0021997500904365>. Accessed: Sep. 28, 2019. doi: 10.1053/ jcpa.2000.0436.
SILVA, M. A. Diet of common dolphins, Delphinus dolphins, off the Portuguese continental coast. Journal of the Marine Biological Association of the United Kingdom, v.79, n.531540. 1999. Available from: <https://www.cambridge.org/ core/journals/journal-of-the-marine-biological-associationof-the-united-kingdom/article/diet-of-common-dolphinsdelphinus-delphis-off-the-portuguese-continental-coast/ CAF529DFFF310488266B5990EC3E0185>. Accessed: Sep. 28, 2019. doi: $10.1017 / \mathrm{S} 0025315498000654$.

SILVA, V. M. F.; R. C. BEST. Tucuxi Sotalia fluviatilis (Gervais, 1853). In: S. H. Ridgway e R. Harrison (Ed.). Handbook of marine mammals: Academic Press, v.5, 1994. Tucuxi Sotalia fluviatilis (Gervais, 1853), p.43-69

SILVA, V. M. F.; R. C. BEST. Sotalia fluviatilis. Mammalian Species, v.527, p.1-7. 1996. Available from: <https://academic. oup.com/mspecies/article/doi/10.2307/3504117/2600725>. Accessed: Sep. 28, 2019. doi: 10.2307/3504117.

SIMÕES-LOPES, P. C. Occurrence of a population of Sotalia fluviatilis Gervais, 1853 (Cetacea, Delphinidae) at its southern limit distribution, Santa Catarina, Brazil. Biotemas, v.1, n.1, p.57-62. 1988. Available from: <https://periodicos.ufsc.br/index. php/biotemas/article/view/23303>. Accessed: Sep. 28, 2019. doi: $10.5007 / \% 25 x$.

STEPHENS, N., et al. Death by octopus (Macroctopus maorum): Laryngeal luxation and asphyxiation in an Indo-Pacific bottlenose dolphin (Tursiops aduncus). Marine Mammal Science, v.33, n.4, p.1204-1213. 2017. Available from: <http://www. marinemammalcenter.org/assets/pdfs/vetsci-stranding/scientificcontributions/2017/indo-pacific-bottlenose.pdf $>$. Accessed: Sep. 28, 2019. doi: 10.1111/mms. 12420 .

STOLEN, M., et al. Fatal asphyxiation in bottlenose dolphins (Tursiops truncatus) from the Indian River Lagoon. PloS one, v.8, n.6, p.e66828. 2013. Available from: <https://journals.plos.org/ plosone/article?id=10.1371/journal.pone.0066828>. Accessed: Sep. 28, 2019. doi: 10.1371/journal.pone.0066828.

WATSON, A.; L. E. GEE. Laryngeal displacement and asphyxiation by a beheaded sheepshead (Archosargus probatocephalus) in a bottlenose dolphin (Tursiops truncatus). Aquatic Mammals, v.31, n.4, p.447. 2005. Available from: <https://www. aquaticmammalsjournal.org/index.php?option $=$ com attachme nts\&task=download\&id=346>. Accessed: Sep. 28, 2019. doi: 10.1578/AM.31.4.2005.447. 